DOI: https://doi. org/10.18371/fp.4(36).2019.190219

JEL Classification G22

\title{
CLIMATE CHANGE: NEW CHALLENGES IN INSURANCE RISK MANAGEMENT
}

\author{
NAHAICHUK Nelya \\ PhD in Economics, associate professor \\ Dean of the Faculty of Management and Law \\ Cherkasy Educational and Scientific Institute \\ University of Banking \\ ORCID ID: https://orcid.org/0000-0002-2014-3151 \\ e-mail:nagaichuk_n@ukr.net
}

\section{SHABANOVA Olena}

$P h D$ in Economics, associate professor

Deputy Dean of the Faculty of Management and Law

Cherkasy Educational and Scientific Institute

University of Banking

ORCID ID: https://orcid.org/0000-0001-9772-6649

e-mail: guryeva.olena@gmail.com

\section{DIDENKO Vladislava}

Bachelor of Higher Education Master's Degree

specialty 073 Management

Cherkasy Educational and Scientific Institute

University of Banking

\begin{abstract}
The article investigates the climatic factors affecting the activities of insurance companies, theoretically describes how climate risks can manifest in different directions of activity of insurance companies. Climate change risks and new business opportunities are identified. Directions have been identified to enhance the role of insurance companies in managing climate-related risks.

Keywords. Climate risks, physical risks, transitional risks, underwriting, agricultural insurance, insurance payments, insurance reserves.
\end{abstract}

Аннотация. B cmaтье исследованы климатические факторы, влияюшие на деятельность страховых компаний, теоретически описано как климатические риски могут проявляться в разных направлениях деятельности страховых компаний. Определены риски, связанные с изменением климата, и новые возможности для страховщиков. Выявлень направления активизации роли страховых компаний в управлении рисками, связанными с климатическими условиями.

Ключевые слова. Климатические риски, физические риски, переходные риски, андеррайтинг, сельскохозяйственное страхование, страховые выплаты, страховые резерBbl. 
Formulation of the problem. Thirty years ago, Swiss Re identified climate change as a new risk and challenge for the insurance business. This topic has been endorsed by society, given its environmental importance. However, at that time it was still not seen as an important business issue [1]. Today, the perception of this issue has changed significantly.

The constant rise in average global temperature is already a fixed fact. Millions of people suffer from the horrific effects of extreme natural disasters, exacerbated by climate change, which cause such extreme natural events as droughts, floods, severe hurricanes, flooding of coastal areas and settlements, abnormal temperatures.

The UN Climate Summit opened in New York on September 23, 2019. Swedish schoolgirl Greta Turnberg was invited to give the opening speech, which drew the international community's attention with her radical speech in defense of the planet's ecology. The climate change process, mainly due to its environmental impact, has the devastating consequences that humankind faces now and will face in the future.

The insurance market plays a huge role in helping to mitigate and respond to natural disasters. At the same time, as a result of the adverse effects of climate change, the insurance business is facing massive insurance losses. Climate change risk management issues are on the agenda.

In the long run, in the absence of adaptation to the effects of global warming, insurers will have to raise prices and, for millions of people, insurance coverage may become inaccessible. In order to prevent such a situation, it is necessary to study the physical risks and to develop adaptation measures to minimize or neutralize their effects.

Analysis of recent research and publications. Conceptual-semantic principles of nature and features of risk management of the insurer attract attention of a considerable number of researchers, in particular, such issues are considered in their works by I. Gerasimova, A. Yermoshenko, M. Zhitar, O. Nepochatenko, N. Tkachenko, S. Yarmolenko, T. Holzhou, J. Turner and other scholars.

However, despite the large number of publications, the topic of climate risk management by insurance companies has not yet been sufficiently researched and described.

The purpose of the article is to find out the impact of climate change on the profile of insurance risks, the peculiarities of the functioning of insurance companies with regard to risk modification and the adjustment of the policy of managing own risks of resilience caused by the risks of climate change.

Research results. According to the Swiss Re Institute [2], the total amount of insurance losses in 2019 was $\$ 56$ billion - 34 billion less than during 2018. The economic losses from natural and man-made disasters in 2019 amounted to about $\$ 140$ billion. Which is also much less than the losses of 2018 (\$ 176 billion). At the same time, analysts notice that the value of insured losses from natural disasters in 2019 also decreased from $\$ 50$ billion to $\$ 34$ billion, less than the loss of the 2018 underwriting year. The decrease in the volume of losses is also noted by the consequences of manmade disasters, their size in 2019 amounted to $\$ 6$ billion. 
Abnormally high rainfall was observed in the central United States, northern Canada, northern Russia and southwest Asia. The average rainfall during the 12 months in the United States bordering the period from July 2018 to June 2019 (962 $\mathrm{mm})$ has been the highest in the history of observations.

Climate change generates "secondary hazards" such as local flooding, heavy rainfall, prolonged drought, severe wildfires and other extreme weather events. Losses from "secondary hazards" are increasing due to rapid development in areas subject to difficult weather conditions and higher temperatures.

More than 13,500 people died or were reported missing in the crash in 2018, which was one of the lowest rates in recent years. Natural disasters have caused the deaths of more than 9800 people, and man-made disasters caused deaths of about 3600 people. 3000 people died in 2017. The human casualties of 2019 caused more than 11,000 deaths. In 2019 a record high temperature was recorded in Australia, India, Japan and Europe and has affected people's health and wellbeing. In Japan, in late July - early August 2019, a strong heat wave occurred, resulting in more than 100 people killed and 18,000 more hospitalized. In the summer 2019, Europe experienced two strong heat waves. A heat wave that hit the southwestern parts of Central Europe in June, led to the deaths of a huge number of people in Spain and France. The strongest heat came at the end of July, affecting most of Central and Western Europe. In the Netherlands, a heat wave led to 2,964 deaths, which is almost 400 more deaths than the average annual week [3].

Food security is deteriorating in some areas of Kenya, Somalia, Uganda, Kenya and Ethiopia due to the scanty season of prolonged rains (gu rains). Overall, in the Horn of Africa, about 12.3 million people are living in food insecurity. In the period from October till November 2019, Somalia was hit by heavy flooding.

Due to the worst floods in some areas of Afghanistan in March 2019, 13.5 million people in rural areas are experiencing food shortages in March 2019, with 22 out of 34 provinces? Which are still recovering from the severe droughts they encountered in 2018 [4].

Cambridge University analysts, who annually release data on the impact of catastrophic events on world GDP, presented a study by Cambridge Global Risk Outlook 2020, according to which, in the face of natural disasters in 2020, the global economy could lose $\$ 179$ billion.

Insurance companies run the risk of losing their property due to extreme weather events. Due to the specific nature of the activity, insurers are particularly aware that climate warming by more than 2 degrees can lead to extremely high environmental risks and the inability to provide consumers with affordable insurance products. Moreover, if the insurance company seeks to reduce its risks by limiting the list of insured events and the amount of insurance payments, then other stakeholders (investors, banks, etc.) will face even more significant and uninsured risks. Therefore, financial institutions need up-front strategies for managing climate change-related risks. 


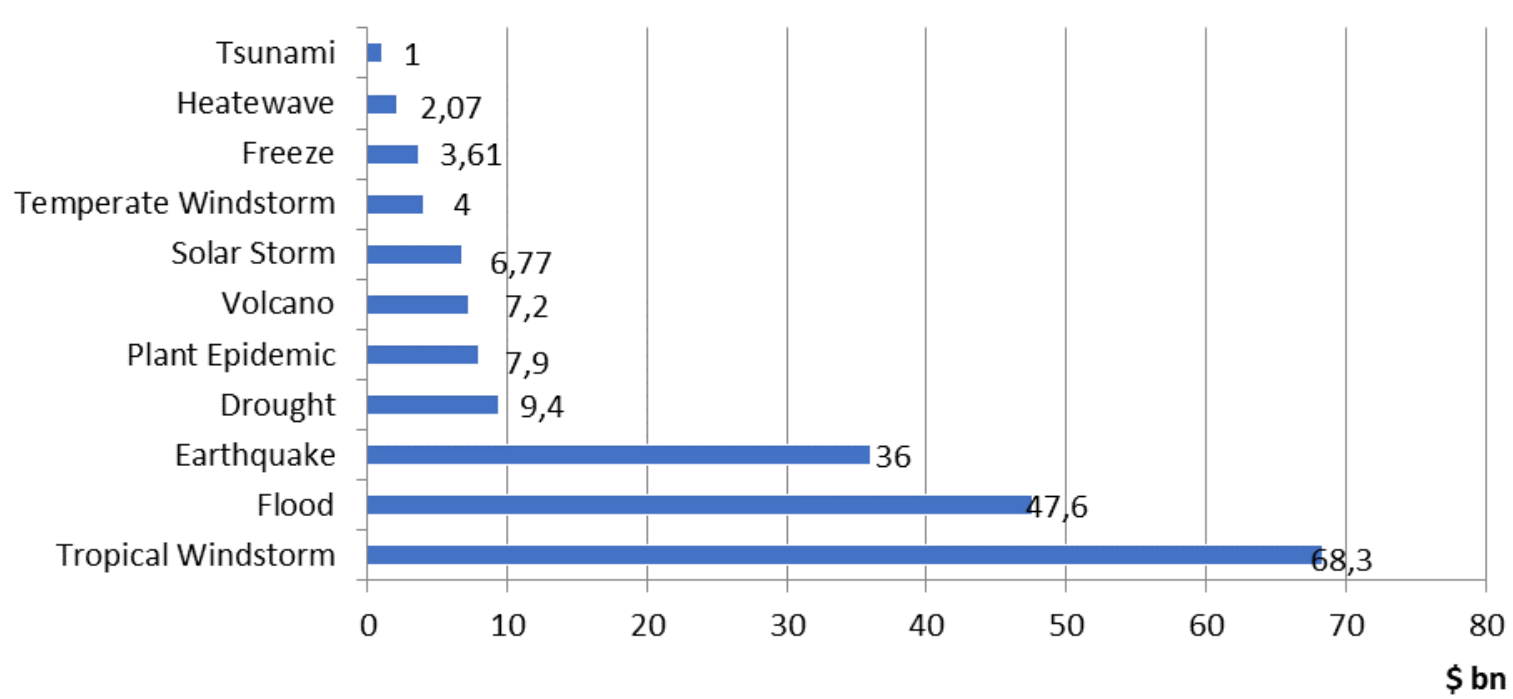

Figure 1. Climate risks and their impact on global GDP in 2020 Source: Created by the authors according to [5]

Climate factors affecting insurance companies generate two main risk categories (Fig. 2).

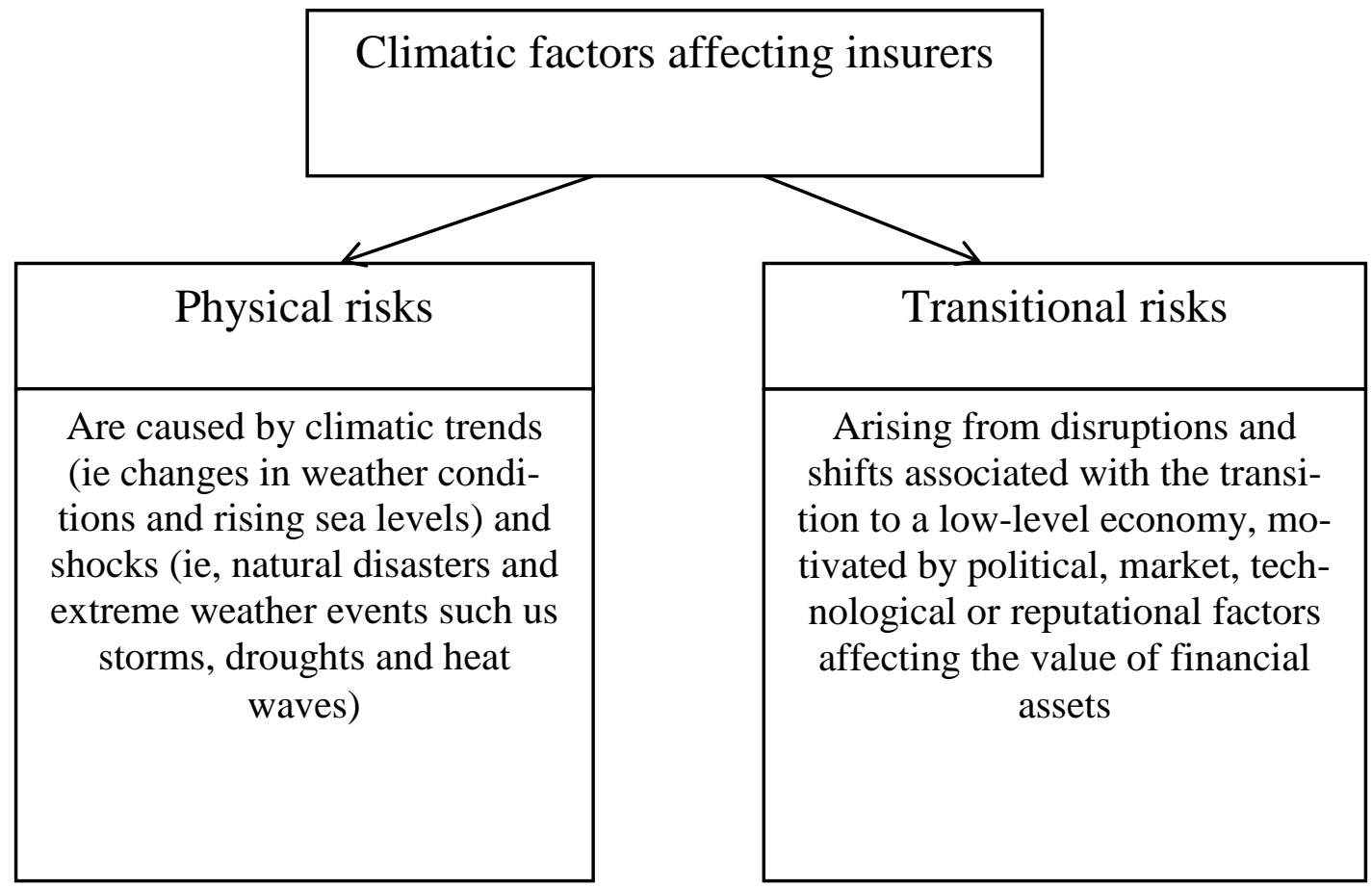

Figure 2. Risks of insurers generated by climatic factors Source: Created by the authors according to [6]

Physical and transitional risks can create different strategic, operational and reputational risks to insurance companies within the insurance and investment business (Table 1). 
Table 1

\begin{tabular}{|l|l|}
\hline \multicolumn{1}{|c|}{ Type of risk } & \multicolumn{1}{c|}{ Characteristic } \\
\hline Underwriting & $\begin{array}{l}\text { Climate change is already affecting the frequency and concentration of } \\
\text { high-impact natural disasters worldwide. This increases the insurance } \\
\text { requirements associated with the weather }\end{array}$ \\
\hline Market & $\begin{array}{l}\text { Insurers' ability to conduct insurance business may be limited by an in- } \\
\text { crease in physical risks to the assets if the risk-based pricing exceeds the } \\
\text { elasticity of demand and the customer's willingness to pay. The shrinking } \\
\text { markets are likely to further increase barriers for consumers to access in- } \\
\text { surance. }\end{array}$ \\
\hline Strategic & $\begin{array}{l}\text { the risk arising from a climate event or scenario (internal or external) may } \\
\text { or may not slow the insurer to achieve its strategic goals. }\end{array}$ \\
\hline Investment & $\begin{array}{l}\text { Insurers' ability to meet future claims can be substantially impaired if cli- } \\
\text { mate risks significantly disrupt capital markets. }\end{array}$ \\
\hline Operating & $\begin{array}{l}\text { The physical impact of the climate can affect the insurer's own assets (in- } \\
\text { cluding property, equipment, IT systems and human resources), leading to } \\
\text { increased operating costs, inhibiting delivery infrastructure or potentially } \\
\text { stopping. }\end{array}$ \\
\hline Reputational & $\begin{array}{l}\text { In recent years, insurance underwriting or investment in climate-friendly } \\
\text { sectors has become a problem for civil society, an example of which is a } \\
\text { well-known public movement calling for the abandonment of coal mining } \\
\text { and the end of coal energy infrastructure underwriting }\end{array}$ \\
\hline
\end{tabular}

Source: Created by the authors according to [6]

There are differences in the impact of climate risks on insurers' activities, depending on their specialization. Yes, non-life insurance companies are most likely to have underwriting obligations that are exposed to physical risks, and as such have more experience in identifying, pricing, and managing such risks. The increasing frequency and severity of natural disasters resulting from climate change in the short term may lead to higher premiums but may prove financially unprofitable for insurers in the long run.

For life insurance companies, in many cases, they are just beginning to study the impact of climate factors on their underwriting portfolios. The potential effects of climate change on population mortality are a priority for actuarial associations studying insurance, annuity and retirement programs. The key here are the health problems associated with warming and extreme weather events.
Reinsurers are often well versed in managing complex systemic risks such as climate change. Due to their dangers in the insurance system and internationally, reinsurers are more resilient to climatic factors through geographical diversification. However, with the severity and frequency of major natural disasters, the availability and cost of reinsurance coverage for risks associated with weather anomalies can become unbearable for smaller insurers in certain markets - potentially leading to a gap in reinsurance [5] . In his speech, Swiss Swiss Re CEO Christian Mementhaler emphasized that global reinsurers can "play a vital role in upholding climate change that goes far beyond our industry" [6]. Today, climate change is a managed risk for reinsurers. However, the growing threat is worrying. Reinsurers can play a key role in driving the transition to a low carbon economy by offering solutions to manage the risks 
associated with large-scale investments in new technologies and innovations.

Extreme heat conditions are increasingly affecting human health and health systems, most affecting countries with aging, urbanization, urban heat island effects, and health inequalities. In 2018, the number of vulnerable people over the age of 65 who have been affected by heat waves has increased by 220 million, a record high compared to the average for the reference period 1986-2005 [7].

The most pronounced climate change risks affecting human health related to heat waves, floods, droughts, fires and transmissible diseases. Millions of lives and medical services can be at risk. Without action, mortality rates and health care costs can rise sharply, leading to significant health, wage and life insurance impacts.

There is an undeniable impetus to further development of the agricultural insurance market, which, as a result of weather anomalies in recent years, agrarians are transferring record amounts of insurance payments.

One of the major effects of climate change is the more volatile nature of precipitation. This poses a threat to crop yields and, in combination with population growth, will pose significant food security challenges for vulnerable countries in the future.

The climatic vulnerability of crops is increasing, and agricultural owners do not yet fully understand the need for rapid adaptation to growing impacts such as floods and droughts. Affordable crop insurance is crucial for agricultural businesses to increase their resilience to climate change, but unfortunately, tradi- tional insurance does not work for them. Insurance protection can be expensive, and insurers will distrust insurance products due to experience of delays or lack of payments.

In the worst case scenario, entire industries and / or geographic regions may lose coverage because of insecurity [8].

International experience has shown that in no country in the world are insurance premiums paid by insurance premiums simply because the premiums are too high. Some of these expenditures are reimbursed by the state. In order to encourage agricultural production in Ukraine in the face of increased agricultural risks, the issue of its financial stimulation must be resolved, in particular through the insurance system, including state support.

Climate change is affecting the insurance market as new insurance risks emerge. Given that climatologists expect an increase in the intensity and frequency of extreme weather events (especially related to water elements - storms, floods, etc.), the risk of damage to private property is increasing. Therefore, for insurers, climate change is more of a threat than a business opportunity. Insurance companies need to adapt to climate change, predicting how changing weather will affect their clients' insurance risks. It requires risk assessment and revision of all corporate procedures (pricing, contracting conditions, risk taking procedures) taking into account the client's risk exposure depending on the industry, the scope of the company (private enterprise, trade, industry), its geographical location, availability of business opportunities and other factors (Table 2). 
Table 2

Climate change risks and new opportunities for insurers

\begin{tabular}{|c|c|c|}
\hline Types of Insurance & Risks (Climate Change Impacts) & $\begin{array}{l}\text { Opportunities (Climate Action } \\
\text { or Climate Change Impacts) }\end{array}$ \\
\hline Property insurance & $\begin{array}{l}\text { an unprecedented increase in the fre- } \\
\text { quency of extreme weather events, } \\
\text { threatening solvency and liquidity; } \\
\text { - it will become more difficult to insure } \\
\text { the risks; } \\
\text { - lack of funds for insurance; } \\
\text { - public sector response based on unreli- } \\
\text { able information; } \\
\text { - Increasing the cost of repair work }\end{array}$ & $\begin{array}{l}\text { - increased demand for insur- } \\
\text { ance and alternative risk trans- } \\
\text { fer; } \\
\text { - the difference in risk can be } \\
\text { estimated in monetary terms; } \\
\text { insurance of Kyoto projects; } \\
\text { - disaster management; } \\
\text { - prototype new prototype } \\
\text { equipment can be insured }\end{array}$ \\
\hline Accident insurance & $\begin{array}{l}\text { - unexpected claims about the duty to be } \\
\text { cautious or to promote the interests of } \\
\text { the company; } \\
\text { - commodity failure (failure of new } \\
\text { products that failed to establish them- } \\
\text { selves in the market under new condi- } \\
\text { tions); } \\
\text { - transport damage (in case of natural } \\
\text { disasters) }\end{array}$ & $\begin{array}{l}\text { - professional services in the } \\
\text { carbon markets; } \\
\text { - "green" transport - new, } \\
\text { more economical means of } \\
\text { transport }\end{array}$ \\
\hline $\begin{array}{l}\text { Life and health } \\
\text { insurance }\end{array}$ & $\begin{array}{l}\text { - episodic health effects; } \\
\text { - underestimation of life expectancy due } \\
\text { to winter warming in the Northern Hem- } \\
\text { isphere; } \\
\text { - lower disposable income due to natural } \\
\text { disasters }\end{array}$ & $\begin{array}{l}\text { - increasing demand for health } \\
\text { insurance; } \\
\text { - economic and welfare } \\
\text { growth in developing countries } \\
\text { as a result of the transfer of } \\
\text { new technologies }\end{array}$ \\
\hline $\begin{array}{l}\text { Other } \\
\text { products }\end{array}$ & $\begin{array}{l}\text { - increase in financial costs due to slow- } \\
\text { down in business activity, - for example, } \\
\text { as a result of power outages; } \\
\text { - loss of opportunities for rest; } \\
\text { - increase of financial costs in the agro- } \\
\text { industrial sector; } \\
\text { new energy-related technologies in risk }\end{array}$ & $\begin{array}{l}\text { - alternative transfer of risks } \\
\text { (bonds related to the risk of } \\
\text { catastrophes, etc.); } \\
\text { - Risks related to R\&D in low } \\
\text { carbon technologies; } \\
\text { - consulting services; } \\
\text { Emissions trading insurance; } \\
\text { - trade risks related to tech- } \\
\text { nology exports; } \\
\text { - Carbon becomes an insured } \\
\text { asset }\end{array}$ \\
\hline
\end{tabular}

Source: Created by the authors according to [9]

Insurers and reinsurers participate in the fight against climate change in three areas:

- compensate for the effects of natural hazards,
- participate in the organization of preventive measures,

- finance economy through longterm investments [10].

New services in the insurance market are designed to support the latest tech- 
nologies that are more efficient and reduce insurance risk. Therefore, insurance companies are interested in introducing new technologies and technological modernization through the use of risk assessment techniques, as well as through discussion of conditions that must be met by environmentally sound technology.

Insurance companies can stimulate the implementation of new technologies in several ways. One of them is insurance of property and technical equipment of the enterprises. Usually after the occurrence of the insured event at the old industrial plant, the insurer shall only reimburse the costs of the restoration of the old technology that existed before the occurrence of the insured event. If appropriate technological modernization of the enterprise, the insurer may assume the obligation to Fund such upgrades upon the occurrence of an insured event, although such insurance will cost more [11].

If we talk about the benefits of investing in climate change, today many people simply do not perceive the consequences of climate change, how events can have a significant negative impact on the economy or their daily lives. But this perception will change for a short time, for example, in the next five to ten years.

One big problem for investors is that it is impossible to know what event or turning point will trigger a change in relationships sufficient to create an "investment catalyst".

Insurers as investors in climate change must take steps to limit the propensity of the economy to scale out, while maintaining the prospect of enormous growth potential brought about by the future paradigm shift.

Investment technologies can be divided into three categories:

1) the evolutionary application of modern technologies (for example, the improvement of lithium ion batteries and the development of a protective screen);

2) new adaptation of modern technology (application of sensors and algorithms for pattern recognition, IoT, robots, light diodes and plant science for growing food in closed vertical farms);

3 ) the revolutionary development of new science (pure meat, algae biofuels) [10].

Despite the growing trend of the magnitude of natural and man-made disasters, consequences of secondary hazards", insurance companies are forced to revise approaches to the management of its own risks, in particular, to upgrade its own reinsurance program. Most often insurers use is proportional to coverage, purchasing quota agreements, which helps them to reduce capital requirements and, at the same time, due to the resulting Commission to Fund the investment required to ensure the financial sustainability of insurance operations of natural disasters and their consequences. However, this resistance cannot be achieved without properly underwriting the risks of natural disasters and "secondary hazards", which requires the improvement of methods of estimation of potential losses.

Although now dominated by proportional reinsurance contracts, however, there has been a trend to use nonproportional reinsurance, in particular the increased demand for the purchase of contracts of excess of loss (risk and catastrophe). The purpose of these coatings 
is to protect the results of operations of insurers by transfer of catastrophe risk to reinsurers.

Recent large losses from events such as Super Typhoon Mangosteen (which swept through the Philippines, Hong Kong, Macau and Guangdong) have raised the attention to the need of protection against catastrophic risks. While the current proposal of the insurance market capacity is sufficient to satisfy the growth in demand for this type of insurance, however, several powerful natural disasters can cause failure of these facilities in the medium and long term.

In 2016, the disaster risk gap was about $\$ 180$ billion in total for natural disasters and the risk of weather - just \$ 80 billion in Asia alone. Altogether, over the past 40 years, $\$ 4$ trillion has been lost in natural disasters, of which 2.9 trillion. $\$$ a trillion from other natural disasters such as an earthquake and tsunami. The United States compensated by insurance more than $1.1 \$$ trillion. On average, only $30 \%$ of economic losses are insured [12].

Swiss Re Institute estimates that total capital in the non-life reinsurance sector (including alternative capital) was over \$ 2 trillion by the end of 2018. USA. Even so, the disaster relief gap in 2017 and 2018 totaled $\$ 280$ billion. Again, more than half of this high level of low insurance was caused by uninsured secondary risk losses [13].

Conclusion. Despite the many potential benefits, to date, adequate insurance coverage for damage caused by extreme weather events and climatic disasters is still not widely available. Even innovative approaches to reducing insurance and administrative costs, as well as pay- ment delays associated with traditional insurance schemes, have low penetration rates.

To manage climate-related risks, insurers are advised to:

1. To move from retrospective underwriting in insurance (the process of analyzing and adopting or rejecting risk insurance), based on past scientific data, to expected underwriting in the future, which takes into account future climate change. The effects of climate change and emergencies are put into risk modeling to assess possible losses and determine the cost of insurance coverage.

2. Underwriting adjustments, higher deductibles, rising prices to compensate for the growing number of insured events. Increasing prices for insurance services can influence the decision making of investing in better building materials or stop construction in high risk areas altogether.

3. Developing new insurance products to diversify risks such as accident bonds and derivatives.

4. Identification of high risk areas for the termination of new construction in such areas, or in order not to insure such facilities.

5. In the process of pricing in construction insurance in high-risk areas, the amount of insurance payments should be limited by dividing it into all insured parties.

From the study can be concluded in General that the effective management of the insurer for its risks, taking into account climate change, is of strategic importance. From that, how much successfully the company can implement its policy in this direction, will depend on its dynamic development. 
The role of global insurers and reinsurers in a changing climate is changing. Already allocated significant sums in the development of solutions to overcome the increasing risk [14] associated with climate change and to reduce the gap in insurance coverage. The accumulated statistics are constructed by insurers to model natural disasters facilitate the risk assessment. In addition, the insurance activities are carried out in the direction of informing and raising awareness among businesses and communities on risks to enhance their sustainability. Using the latest technology, insurers can improve their possibilities of modelling risks and develop new solutions for the primary and secondary hazards to help reduce the uninsured risk of a crash. To limit global warming requires the participation of a "just society". Cooperation between insurance companies, reassurance and the public sector can make the world more stable, more compatible with life, growth and development. The impact of climate change becomes more obvious and important, but at the same time this opens up great opportunities. Thanks to the cooperation can be introduced and implemented for more practical and reliable model of insurance. The establishment of a strong economy and social stability is a matter of global interest and sustainable future should be a collective choice.

\section{References}

1. Gloor, M. \& Perils, C. (2019). Insurance in a world of climate extremes: what latest science tells us. Retrieved from: https://www.swissre.com/institute/research/topics-and-risk-dialogues/natcat-andclimate/insurance-world-climate-extremes.html.

2. Bevere, L., Holzheu, T. \& Wong, C. (December, 2019). Global catastrophes caused USD 56 billion insured losses in 2019, estimates Swiss Re Institute. Retrieved from: https://www.swissre.com/media/news-releases/nr-20191219-globalcatastrophes-estimate.html.

3. Natural catastrophes and man-made disasters in 2018: "secondary" perils on the frontline. Retrieved from: https://www.swissre.com/dam/jcr:c37eb0e4-c0b94a9f-9954-3d0bb4339bfd/sigma2_2019_en.pdf.

4. 2019 concludes a decade of exceptional global heat and high-impact weather. Retrieved from: https://public.wmo.int/en/media/press-release/2019-concludesdecade-of-exceptional-global-heat-and-high-impact-weather.

5. Globalnyiy prognoz riskov na 2020 god. Kak povliyayut katastroficheskie yavleniya na mirovoy VVP? [Global Risk Forecast for 2020. How will catastrophic 
$\begin{array}{llll}\text { events affect } & \text { global } & \text { GDP?]. } & \text { Retrieved }\end{array}$ https://forinsurer.com/news/19/12/27/37568 [in Russian].

6. Issues Paper on Climate Change Risks to the Insurance Sector. Retrieved from: https://www.iaisweb.org/page/consultations/closed-consultations/2018/draftissues-paper-on-climate-change-risks-to-the-insurance-sector.

7. Weymann, M. \& Bolli, C. ( December, 2019). Championing climate action. Retrieved from: https://www.swissre.com/risk-knowledge/mitigating-climaterisk/swiss-re-decarbonises-its-business-model.html.

8. Swiss Re Nazvala 5 novyih riskov s vyisokim vozdeystviem na strahovuyu otrasl [Swiss Re Names 5 New Risks with High Impact on the Insurance Industry]. Retrieved from: https://forinsurer.com/news/19/06/14/36897 [in Russian].

9. Klimaticheskie izmeneniya nesut $\mathrm{v}$ sebe sereznyie vyizovyi dlya strahovschikov - glava SCOR [Climate change poses serious challenges for insurers SCOR head]. Retrieved from: http://tristar.com.ua/1/news/klimaticheskie_izmeneniia_nesut_v_sebe_sereznye_vyzo vy_dlia_strahovshikov__glava_scor_12234.html [in Russian].

10. Dlugoleski, E. \& Lafeld, S. (2005). Izmenenie klimata $i$ finansovyiy sektor: perspektivyi deyatelnost [Climate Change and the Financial Sector: Prospects]. Retrieved from: https://wwf.ru/upload/iblock/731/cc_andfinansial.pdf [in Russian].

11. Klimatologiya strahovaniya [Climatology of insurance]. Retrieved from: http://www.ins-union.ru/rus/klimatologiya [in Russian].

12. Strahovschiki stalkivayutsya $\mathrm{s}$ mnogochislennyimi riskami $\mathrm{v}$ svyazi $\mathrm{s}$ izmeneniem klimata [Insurers face multiple climate change risks]. Retrieved from: https://allinsurance.kz/articles/insurance-technologies/9678-strakhovshchikistalkivayutsya-s-mnogochislennymi-riskami-v-svyazi-s-izmeneniem-klimata [in Russian].

13. Holzheu, T. \& Turne, G. (2018). The Natural Catastrophe Protection Gap: Measurement, Root Causes and Ways of Addressing Underinsurance for Extreme Events $\uparrow$, The Geneva Papers on Risk and Insurance - Issues and Practice, Palgrave Macmillan;The Geneva Association, vol. 43(1), pages 37-71.

14. Secondary natural catastrophe risks on the front line. (2019). Retrieved from: https://www.swissre.com/institute/research/sigma-research/sigma-2019-02.html. 